\title{
Pengaruh Pembelajaran Iklan di Sekolah dalam Meningkatkan Kreativitas Peserta Didik
}

\author{
Maudy Haikal Abdila* \\ Email: maudyhaikal01@gmail.com \\ *Program Studi Pendidikan Bahasa dan Sastra Indonesia, Universitas Riau
}

\section{Pengantar}

Salah satu tolak ukur pembelajaran yang baik yaitu tercapainya kompetensi yang sudah tertera di setiap mata pelajaran. Dalam mata pelajaran Bahasa Indonesia, salah satu tolak ukur keberhasilan siswa yaitu menguasai dan mengimplementasikan iklan dalam kehidupan sehari-hari. Artikel ini bertujuan untuk memaparkan cara membentuk kreativitas peserta didik melalui pembelajaran iklan di sekolah.

Pemaparan ini berisi wawasan mengenai dua hal, yaitu (1) peran guru dalam membimbing peserta didik dan (2) cara yang perlu dilakukan untuk mewujudkan peserta didik yang kreatif melalui pembelajaran iklan. Dua aspek penting tersebut yang menjadi tolak ukur dalam mewujudkan kreativitas peserta didik, perlu adanya kerjasama antara pendidik dan peserta didik untuk mendapatkan hasil yang diinginkan.

\section{Pendidikan}

Undang-undang No. 20 Tahun 2003 tentang Sisdiknas pada pasal 3 menyatakan bahwa Pendidikan nasional berfungsi mengembangkan kemampuan dan membenuk watak serta peradaban bangsa yang bermartabat dalam rangka mencerdaskan kehidupan bangsa, bertujuan untuk berkembangnya potensi peserta didik agar menjadi manusia yang beriman dan bertakwa kepada Tuhan Yang Maha Esa, Berakhlak mulia, sehat, berilmu, cakap, kreatif, mandiri, dan menjadi warga negara yang demokratis serta bertanggung jawab. 
Bahasa Indonesia yang berkedudukan sebagai bahasa nasional digunakan sebagai alat pengembangankebudayaan nasional, ilmu pengetahuan dan teknologi. Kebudayaan nasional yangberagam, rasanya sulit disebarluaskan kepada seluruh masyarakat yang juga beragam bahasa daerah dengan menggunakan bahasa selain bahasa Indonesia. Hal ini juga berlaku dalam penyebarluasan ilmu pengetahuan dan teknologi modern.

Proses belajar merupakan inti dari proses pendidikan secara keseluruhan. Dalam pendidikan membutuhkan sebuah proses yang panjang tentunya, semua kegiatan yang dilakukan dalam pendidikan adalah proses belajar. Belajar diartikan sebagai proses perubahan tingkah laku dari individu berkat adanya interaksi antara individu dan individu dengan lingkungannya. Perubahan yang berarti bahwa seseorang setelah mengalami proses belajar, akan mengalami perubahan tingkah laku, baik aspek pengetahuan, keterampilan, maupun aspek sikap (Usman, 2003).

Guru hendaknya bisa membuat kualitas belajar siswa semakin meningkat. Jika kualitas belajar menurun, maka dapat memberikan dampak mutu capaian belajar wawasan dan pengalamannya (Zulhafizh, Atmazaki, \& Syahrul, 2013). Semua proses belajar di dalam pendidikan Indonesia bergantung kecapakan guru yang mengajarkan peserta didik. Perlu guru yang profesional dan berkarakter agar tercipta lingkungan pendidikan yang harmonis.

\section{Iklan}

Iklan sudah diajarkan sejak sekolah dasar yang termaktub dalam tema dan subtema yang diajarkan. Di sekolah menengah pun iklan juga diajarkan sebagai bentuk penawaran produk dengan bahasa yang tertata. Sebagian besar bahkan seluruh perusahaan menawarkan produknya dengan iklan, selain itu ada juga iklan layanan masyarakat dan penawaran kerja. Iklan dimuat dimana-mana baik di media cetak maupun media elektronik, kita akan menemukan iklan kapanpun baik ketika di jalan, di rumah, di tempat kerja, di sekolah, serta banyak lagi.

Iklan dipelajari agar peserta didik mengerti tentang unsur kebahasan iklan 
yang sangat penting untuk mereka di masa depan. Bahasa iklan merupakan bagian dari ragam bahasa jurnalistik. Bahasa iklan memiliki sifat yang sama dengan bahasa media massa, yakni bersifat singkat, padat, sederhana, lancar, jelas, lugas, dan menarik. Selain sifat-sifat yang telah disebutkan sebelumnya, sifat yang paling menonjol adalah bahasa iklan harus persuasif. Hal ini bertujuan agar iklan yang ditawarkan dapat menarik minat pembaca iklan untuk membeli iklan yang ditawarkan.

Iklan yang akan dibahas ini yaitu iklan penawaran barang dan jasa karena dalam iklan penawaran barang dan jasa terdapat kalimat persuasif dan gambar yang menarik. Peserta didik akan lebih bisa berkreativitas melalui gambar dan kaliat yang dibuat pada iklan penawaran barang dan jasa tersebut.

\section{Pembelajaran tentang Iklan yang Membentuk Kreativitas Peserta Didik}

Hadirnya kurikulum memberikan arah tujuan yang jelas di satuan pendidikan. Kurikulum mampu membawa dan memberikan pengalaman bagi pelaksananya. Kurikulum semacam pintu gerbang yang memberikan gambarangambaran yang diperjuangkan untuk dicapai. Pengalaman dan tindakan yang akan dilakukan bisa segera dipikirkan dan dirancang. Segala yang ditargetkan dan diinginkan bisa diwujudkan secara bersama-sama melalui rancangan dan panduan yang ada. (Zulhafizh, 2020)

Materi iklan ini masuk ke dalam kurikulum bahasa Indonesia yang ada di sekolah-sekolah. Dengan mempelajari iklan peserta didik akan dapat membuat iklan sesuai kaidah kebahasaan masing-masing jenis iklan. Bermacam-macam cara yang dapat dilakukan guru agar iklan menjadi ajang bagi peserta didik dalam berkreativitas.

Kreativitas merupakan kemampuan menciptakan sesuatu yang baru yang lebih inovatif serta memperbaiki sesuatu yang lama agar lebih bervariasi. Kreativitas yang ada di dalam peserta didik meliputi menciptakan sesuatu, memodifikasi sesuatu dan mengkombinasikan sesuatu. 


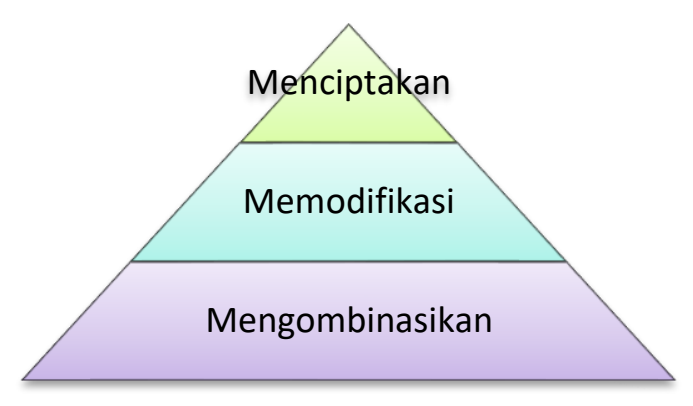

Gambar 1. Jenis-jenis kreativitas

\section{Menciptakan}

Menciptakan adalah membuat sesuatu dari yang tidak ada menjadi ada. Guru dapat memberikan tugas kepada siswa agar siswa menciptakan iklan yang kreatif dengan membuat gambar dan slogan-slogan serta implikatur yang dapat dipelajari peserta didik pada saat membuat iklan. Proses menciptakan ini haruslah sejalan dengan pengetahuan yang ada di dalam diri peserta didik tentang unsur kebahasaan dalam iklan.

Peserta didik harus mengetahui struktur iklan, membedakan implikatur dan mengidentifikasi jenis-jenis iklan. Iklan yang kreatif tidak akan tercipta jika sang pembuat tidak mempunyai wawasan yang luas tentang iklan. Guru harus memberikan apresiasi kepada peserta didik yang sudah menciptakan iklan baik dalam segi gambar iklan tersebut maupun segi tulisan yang dibuat. Dengan begitu kreativitas peserta didik akan lebih berkembang.

\section{Memodifikasi}

Peserta didik dapat memodifikasi iklan yang sudah ada dengan membuatnya lebih kreatif dan inovatif. Memang dalam hal memodifikasi membuat iklan tersebut terkesan sama dengan iklan yang dimodifikasi, tetapi peserta didik bisa meminimalisirnya dengan membuat iklan dengan tema yang sama tanpa mengambil sedikitpun tulisan dan gambar iklan tersebut.

Guru dapat mengkoordinir peserta didik dengan memberi petunjuk dalam 
pembuatan iklan tersebut. Contoh-contoh iklan yang beredar di masyarakat juga dapat digunakan guru agar peserta didik lebih kreatif dalam membuat iklan. Memodifikasi iklan tidak sesulit menciptakan, tipe kreativitas ini lebih mudah digunakan oleh pendidik karena akan sangat membantu dalam meningkatkankreativitas. Guru dapat memberikan contoh-contoh iklan yang pouler kepada peserta didik dalam membuat suatu iklan yang baru.

\section{Mengombinasikan}

Mengombinasikan adalah menggabungkan dua hal yang berbeda. Dalam membuat iklan, mengombinasikan dapat dilakukan dengan cara menciptakan dan memodifikasi. Dapat dikatakan bahwa mengombinasikan adalah sebuah kreativitas yang paling baik di antara tipe kreativitas lainnya. Dengan mengombinasikan dua hal, maka iklan tersebut akan lebih baru dan lebih unik. Guru dapat membimbing siswa dengan mencontohkan iklan yang bisa dikombinasikan. Setiap siswa mempunyai kreativitas masing-masing, guru haruslah lebih cakap dan peka akan hal itu. Maka dari itu, guru dapat membiarkan peserta didik berkreativitas sendiri sesuai aturan membuat iklan yang berlaku.

\section{Simpulan}

Ada banyak cara yang bisa dilakukan oleh guru dalam meningkatkan kreativitas peserta didik, khususnya pada pembelajaran bahasa Indonesia di sekolah. Selain peserta didik, guru juga dituntuk lebih kreatif dalam menentukan pendekatan, metode, teknik, dan strategi dalam pembelajaran sehingga hasil pembelajaran akan maksimal. Dalam kaitannya dengan aplikasi pembelajaran, pengajaran iklan lebih ditekankan pada pembuatan RPP, khususnya pada penentuan kompetensi dasar, indikator, materi, langkah-langkah pengajarannya, dan evaluasinya. Iklan yang dipilih berupa iklan yang berkaitan dengan kebutuhan siswa seperti iklan motor, laptop, internet, dll. Melalui pembelajaran ini, siswa diharapkan mampu memproduksi iklan sendiri. Selain itu, siswa diharapkan mampu 
membuat iklan sendiri sesuai dengan struktur dan bahasa iklan yang baik. Setiap siswa mempunyai kreativitas masing-masing, guru haruslah lebih cakap dan peka akan hal itu. Maka dari itu, guru dapat mebiarkan peserta didik berkreativitas sendiri sesuai aturan membuat iklan yang berlaku.

\section{Referensi}

Anwar, Rosihan. (2004). Bahasa Jurnalistik Indonesia dan Komposisi. Yogyakarta. Media Abadi.

Brown, Gillian dan George Yule. (1996). Analisis Wacana. Jakarta: PT Gramedia Pustaka Utama.

Chaer, Abdul. (2010). Bahasa Jurnalistik. Jakarta: Rineka Cipta.

Ihsan, Diemroh. (2002). Pragmatik, Analisis Wacana, dan Guru Bahasa. Palembang: Universitas Sriwijaya.

Liliweri, Alo. (1992). Dasar-dasar Komunikasi Periklanan. Bandung: Penerbit Citra Aditya Bakti.

Nurcahyo, Arief. (2018). Penerapan Metode Pembelajaran Talking Stick dalam Upaya Peningkatan Hasil Belajar Pokok Bahasan Iklan, Sarana Komunikasi pada Kelas VIII SMPN 1 Singosari. Jurnal PTK dan Pendidikan, 4(1), 79-88.

Zulhafizh, Atmazaki, \& Syahrul R. (2013). Kontribusi Sikap dan Motivasi Belajar Siswa terhadap Hasil Belajar Bahasa Indonesia. Jurnal Bahasa, Sastra dan Pembelajaran, 1(2), 13-28.

Zulhafizh. (2020). Orientation on Implementation of Learning Curriculum at Senior High School: Teacher's Perspective. Jurnal PAJAR (Pendidikan dan Pengajaran), 4(2), 303-315.

\section{*Data Penulis}

Maudy Haikal Abdila, lahir di Pasir Pangarayan, 14 Mei 2002. Pernah bersekolah di TK Dharma Wanita Sungai Salak, SDN 015 Sungai Salak, MTsN 2 Indragiri Hilir, dan SMAN 1 Tempuling.

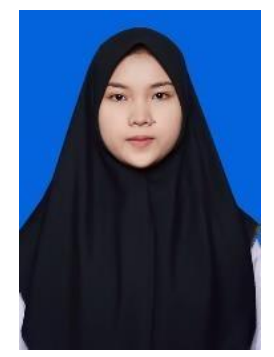

Pada tahun akademik 2020 - 2021, ia melanjutkan studi pada strata satu Jurusan Pendidikan Bahasa dan Seni di Program Studi Bahasa dan Sastra Indonesia FKIP Universitas Riau melalui jalur SBMPTN (Seleksi Bersama Masuk PerguruanTinggi). Karya-karya yang sudah dihasilkannya yaitu empat cerpen yang berjudul Just One Day, Askara, Latah dan Lentera Aksara Nusantara. 
Kontak:

HP/WA : 082268066854

Email : maudyhaikal01@gmail.com

Facebook : Maudy Haikal Abdila

Instagram : @maudyabdila 